УДК 821.161 .2

Гурдуз А. I.

кандидат філологічних наук, доцент кафедри української літератури та методики навчання Миколаївського національного університету імені В. О. Сухомлинського

Хохлова А. I.

студентка української філології Миколаївського національного університету імені В. О. Сухомлинського

\title{
ФАКТОР КОЛЬОРУ В «ЖІНОЧОМУ» МІСТИЧНОМУ ЛЮБОВНОМУ РОМАНІ УКРАЇНИ ПОЧАТКУ ХХІ СТОЛІТТЯ
}

Проаналізовано закономірності колористики романів Л. Баграт «Зло», Дари Корній «Гонихмарник», М. Ряполової «Бурецвіт» $i$ В. Гранеиької «Мантра-омана». Виявлено логіку використання кольороназв відносно жанрової природи творів, принципів їх сюжетного розгортання, а також специфічних авторських акцентів. Показано, що колористична система відіграє особливу роль у моделюванні міфосвіту аналізованих романів.

Ключові слова: традиція, колористика, символізм, логіка, фентезі, відповідність, амбівалентність, міфотворчість.

Проанализированы закономерности колористики романов Л. Баграт «Зло», Дары Корний «Гонитель туч», М. Ряполовой «Буроивет» и В. Гранеикой «Мантра-омана». Выявлена логика использования иветоназваний относительно жанровой природы произведений, принципов их сюжетного развёртывания, а также специфических авторских акиентов. Показано, что колористическая система играет особую роль в 
моделировании мифомира анализируемых романов.

Ключевые слова: традиция, колористика, символизм, логика, фэнтези, соответствие, амбивалентность, мифотворчество.

In this article the regularities of colouristics of the novels «The Evil» by L. Bagrat, "The Persecutor of Clouds» by Dara Korniy, «Buretsvit» by M. Ryapolova, and "Mantra-omana» by V. Granetskaya are analysed. It is discovered the logic of used of coloratives comparatively of these works genre nature, principles of its plot deployment, and also of the specific authors' accents. It is shown, that the colouristics system plays special role in modeling of the analysed novels mythspace.

Keywords: tradition, colouristics, symbolism, logic, fantasy, accordance, ambivalence, mythocreation.

«Жіноча» містична любовна проза як складова масової літератури нині особливо популярна серед читачів не тільки в силу актуальності порушуваних у ній тем і проблем. Саме в цьому художньому корпусі особливо яскраво відбивається нинішній специфічний міжкультурний діалог, у першу чергу, західної й вітчизняної літературно-мистецьких традицій; програються - як у частині фентезійної міської прози - сміливі соціально орієнтовані експерименти в руслі пошуків актуальної національної міфології тощо. Нарешті, автори «жіночого» роману, за оцінкою критики - і не тільки вітчизняної, демонструють вельми високі художні показники. Між тим, досліджується українська «жіноча» містична проза переважно аспектно (С. Філоненко, А. Соколова, Л. Романенко й ін.), a отже, говорити про цілісне осягнення концепції ії автора не доводиться. Нешироке коло задіюваних при цьому літературознавчих методів зумовлює відповідно обмежені результати студій (переважно застосовуються в гендерному аранжуванні образний, проблемнотематичний аналіз із фрагментним звертанням до компаративного i міфопоетичного), i це переконує в необхідності комплексного опрацювання корпусу «жіночої» прози, доцільності поєднання досягнень студій філологів, культурологів, психологів та інших фахівців у цьому. 
Варто звернути увагу в «жіночій» містичній романістиці на перспективний для вивчення тут колористичний аспект (у єдиній системній праці цього профілю доведена можливість міфотворчої ролі колористики в означеній прозі [Гурдуз 2015], відповідні акценти щодо контекстних творів також уже ставилися [Гурдуз 2014 Міфопоетика:67]). У пропонованій статті вперше в зіставленні аналізуємо колористичний аспект у досить помітних в українській літературі початку XXI ст. і таких, що пов’язані певною логікою, романах Людмили Баграт «Зло» (2001р.), Дари Корній (Мирослави Замойської) «Гонихмарник», Марії Ряполової «Бурецвіт» (2010р.) і Вікторії Гранецької «Мантра-омана» (2011р.), причому стосовно «Зла» i «Мантри-омани» студіювання колористики здійснюється також уперше. Беручи до уваги важливість для художнього світу цих письменниць (i для їх указаних романів) аспекту кольору та надзвичайну продуктивність розвідок із кольористики щодо класичної й новішої літератури - доробків Т. Шевченка (А. Критенко), Лесі Українки (О. Рисак, Л. Шулінова), О. Гончара (М. Гуменний), Л. Костенко (Г. Губарева), Я. Коласа (Ю. Бабіч) та ін. - у контексті активного вивчення літератури в системі мистецтв, саме в заявленому ракурсі вважаємо за доцільне проаналізувати названі поворотні для мисткинь твори. Метою нашої розвідки бачиться виявлення логіки використання кольороназв у вказаних романах Л. Баграт, Дари Корній, М. Ряполової і В. Гранецької відносно а) жанрової природи цих творів, принципів їх сюжетного розгортання, а також б) специфічних авторських акцентів.

Обрані для розгляду романи практично не вивчені (деякі 3 них наприклад, книга Дари Корній - швидше, прокоментовані в рецензіях й небагатьох статтях), хоча тепло зустрінуті читачем і високо оцінені на літературних конкурсах: так, «Зло» - дипломант Всеукраїнського конкурсу романів, кіносценаріїв та п’єс «Коронація слова» 2001 р., «Гонихмарник», крім іншого, посів III місце на цьому конкурсі в 2010 р., а «Мантра- 
омана»- I місце в 2011 р.; «Бурецвіт» же нагороджений Європейським співтовариством наукової фантастики («Eurocon - 2011»). Перший комплексний аналіз міфопоетики «Гонихмарника» Дари Корній [Гурдуз 2012] і «Мантри-омани» В. Гранецької [Гурдуз 2014] запропоновано А. Гурдузом, так само як і перше зіставлення міфопоетики «Гонихмарника» i «Зла» Л. Баграт [Гурдуз 2014 Міфопоетика].

Позначені впливом, зокрема, північноамериканських фентезійних зразків, аналізовані твори мають власну національну специфіку, діалогізуючи одночасно зі слов'янською фольклорно-літературною традицією. Структуровані «Зло», «Гонихмарник», «Бурецвіт» і «Мантраомана» відносно традиційно для їх жанрової групи. Героїні книг - творчі, вольові, сильні й, за великим рахунком, самотні натури, які в пошуках долі (чи допомагаючи іншій людині - як у «Бурецвіті») проходять специфічні символічні перепони (певні ініціації) і перебувають при цьому ніби між двома світами (що і передбачає відповідний художній канон): дійсністю й ірраціональним простором. Мова йде, зокрема, про тип героїні-борця, рятівниці, якій дано виступити в традиційно чоловічій ролі. Якщо в «Гонихмарнику» дівчина Аліна визволяє душу коханого (Сашко-Кажан) й набуває надзвичайну надприродну силу (жіноче характерництво), то у «Злі» Марго сходить у паралельний реальності світ обранця Яна, борючись за своє почуття (пригадується й героїня «Містичного вальсу» Наталки Шевченко 2003 р.). Лірина в романі М. Ряполової також допомагає невдачливому Бурецвіту не стати жертвою злого начала і віднайти себе, а зустріч із померлим коханим по той бік реальності для Єви в «Мантріомані» - швидше, іiі діалог із совістю, який дає можливість розв'язати не вирішуваний інакше конфлікт, стати краще.

Ідейно-художні концепції аналізованих творів визначають прогнозоване для фентезійної логіки протиставлення двох начал не тільки на сюжетному чи образному рівнях. Сюжетний стрижень сформовано в 
них як своєрідний квест, де ключову роль відіграє героїня. На розкриття закладеного ідейного конфлікту з більш чи менш вираженою дидактичною розв’язкою орієнтовано і поетикальний шар цих творів, зокрема, їх специфічну колористичну систему (для забезпечення максимальної точності висновків до аналізу залучаємо, передовсім, первинний рівень колористики в романах - власне кольоропозначень).

Очікуване протистояння світлого і темного начал утілене в суттєвій кількісній сумарній перевазі вживаності відповідно лексем на позначення білого і чорного кольорів порівняно 3 кожним іншим окремо взятим кольором у текстах аналізованих книг, причому чорний безумовно домінує. Так, у творі Дари Корній фіксуємо 29,7 \% випадків уживань лексем на позначення чорного і 17,7 \% - на позначення білого кольору від загальної кількості кольороназв у романі, у тексті М. Ряполової відповідно 19,2 \% і 10,6 \%, у романі Л. Баграт - 35,2 \% проти 6,8 \% і тільки в книзі В. Гранецької - 21,1 \% слововживань на позначення чорного до 26,8 \% - на позначення білого кольору. Підкреслення уявної нездоланності темного начала в художній тканині «Зла», «Гонихмарника» і «Бурецвіта», слабкості людини перед спокусою в «Мантрі-омані» певною мірою пояснює таке співвідношення в парі «чорний - білий» у колористичній системі цих книг, однак не визначає окреслену логіку вповні; крім того, важлива фінальна - і традиційно повчальна - перемога тут сил добра.

Характерний для описів зовнішності і загалом способу життя Сашка 3 «Гонихмарника» чорний колір символізує й темний бік душі героя: «Юнак, вдягнений у все чорне, стояв... підпираючи плечем стовбур акащії. Дерево сипало на його чорне волосся, котре сягало рамен, сніжні пелюстки» [Корній 2010:18]. Уже в наведеному фрагменті портрета персонажа неявним контрастом намічено розкол його особистості (ігровий момент - співіснування в його тілі двох душ) і майбутню боротьбу ворожих начал. Те, що після звільнення Сашка-Кажана від присутності зла 
чорний колір залишається в його зовнішньому описі [Корній 2010:330], свідчить про підкреслення письменницею постійності перебування людини на перехресті добра і зла й актуальності в житті відповідного вибору. Однозначність синонімії злого і чорного спостерігаємо в разі такого сполучення в постаті Градобура [Корній 2010:104].

Чорний колір у романі «Зло» також часто увиразнює недобре начало (показові страхи Марго - постать містичного Чорного Незнайомця й под.; пригадаймо співвідносний образ Ловця Снів із «Мантри-омани»), хоча близький зоні комфорту героїні («Чорний, сірий і рожевий - кольори моєї кімнати. Вони заспокоюють» [Баграт 2002:64]). У «Бурецвіті» чорний $\epsilon$ атрибутом чарівника Моротемна, на що орієнтує вже його ім'я («мор» + «mемний»), в якому обіграно наймення Мари або Марени (Морени) богинь давніх слов'ян (до слова, імена ключових персонажів «Гонихмарника» i «Бурецвіта» відбивають стосунок їх власників до ірраціональної сфери: Кажан і Градобур, Бурецвіт і Моротемн). Традиційно з чорним у головного героя роману М. Ряполової пов'язані переживання страху, роздратованості тощо.

Виразне позитивне символічне наповнення авторки аналізованих романів, природно, відводять білому, і тільки в «Мантрі-омані» цей колір панівний стосовно вживаності інших: 26,8 \% кольороназв. У «Гонихмарнику» він асоціюється 3 допомогою вищих сил, надією. Так, закоханим Аліні й Сашку допомагає постать у білому - святий ЮрійЗмієборець, покровитель Львова; вдягнений протягом дії роману у чорне, Сашко-Кажан 3'являється в білому, коли між ним і Аліною виникають почуття [Корній 2010:127]. Відтінок містичності може мати білий колір у «Бурецвіті», причому, як і в попередньому творі, цей колір тут асоціюється 3 небесним (зокрема, в епізоді, коли герої відправляються виконувати чергове завдання русалок і йдуть білим коридором [Ряполова 2010:16], ототожнюваним тут із вірним шляхом). 
Інтрига відношень колірних аспектів в аналізованих романах пояснюється актуалізацією письменницями амбівалентності символіки ключових кольорів і ситуативною логікою художніх текстів. Отже, домінантність чорного в «Гонихмарнику» підкріплена і його специфічним еротизмом, адже еротика - «єдина сфера, де чорний колір має життєстверджувальне начало» [Браэм 2009:113], а перед нами, в першу чергу, - любовний роман. 3 іншого боку, домінування в тексті «Бурецвіта» окремо взятого зеленого кольору (24\% випадків уживань кольороназв від загальної кількості кольоропозначень у романі) мотивоване провідною в книзі рослинною темою. Специфіка хронотопу «Гонихмарника», пов'язаність і зумовленість його міфопоетики системним звертанням Дари Корній до «Тіней забутих предків» М. Коцюбинського і «Лісової пісні» Лесі Українки та їх атмосфери [детальніше див.: Гурдуз 2012:231-233] також пояснюють, чому в романі третім за частотністю використання стає зелений колір: 12,5\% відповідних кольороназв від кількості вживань кольоропозначень. Символічно, що протягом довгого часу героїнярятівниця Аліна зображена саме 3 зеленим волоссям і що іiі мати «...виросла в глухому волинському поліському селі» [Корній 2010:58]. Крім того, для Сашка зелений асоціюється, в першу чергу, з коханням: «...Аліна на Смотричі, мов ангел у зеленому вінку з ї̈ волосся, а за спиною крила, зіткані з південного вітру» [Корній 2010:228]. Не варто забувати в контексті розмови про «жіночу» прозу і те, що зелений колір символізує саме жіноче начало [див.: Браэм 2009:153].

Показову картину отримуємо, приймаючи за $100 \%$ загальну кількість згадувань одного кольору в текстах «Зла» i «Мантри-омани» відповідно в сприйманні його героїнями творів під час їх свідомої активності і сну (чи іншого переживання ірреальності). У «Злі» зелений як маркер живого і дійсного героїня бачить тільки наяву (у 100 \% випадків уживання кольоративів); переважно в реальності зосереджений тривожний 
для Марго червоний (у $71 \%$ від усіх випадків згадувань таких кольороназв). Парадоксально, але сон і його світ для Марго пов’язаний, швидше, з білим кольором (81\%), тимчасом як чорний (тобто асоційовані 3 ним страх, переживання сторонності щодо світу, проявів зла - і водночас він бажаний колір для героїні) співвіднесено 3 явою (74 \% кольоративів). Так само закономірно розподілено у «Злі» й кольороназви жовтого: в описі реального життя Марго частка жовтого - ситуативно як знаку хвороби, розкладу - складає 78 \%, а в снах героїні - світі для неї ідеальному жовтого значно менше (22 \%). У «Мантрі-омані» ж, навпаки, лексеми на позначення жовтого сконцентровані в описах ірреальної активності героїні (кома) - 83 \%, підкреслюють незрозумілість ситуації для Єви, іiі страх, власне «оману». В уявному житті Сви В. Гранецької переважають і кольороназви білого (64 \%), що також мотивоване подвійністю семантики цього кольору: символізацією чистоти, урочистості, святості, але й небуття смерті.

Асоційований у досліджуваних романах із традиційно властивими йому характеристиками ніжності, душевної чистоти колір неба блакитний (2,2 \% від кількості вживань кольороназв у «Злі», 8,9 \% - у «Гонихмарнику», 4,8\% - у «Бурецвіті» і $7 \%$ - у «Мантрі-омані»). Присутність тут синього кількісно співвідносна 3 часткою блакитного кольору (відповідно 2,2 \%, 1 \%, 2,9 \% і 3,5 \%) і відчутну роль відіграє вже в поєднанні 3 ним.

Належність аналізованих романів до міського фентезі і час написання також накладають відбиток на їх тексти. У першу чергу, актуалізований у цьому ракурсі сірий колір 3 його помітною роллю i співмірною присутністю в «Гонихмарнику» - 7,8 \%, «Бурецвіті» - 10,6 \% і «Мантріомані» - 7,7 \% та базовим щодо стереотипу міських «залізобетонних джунглів» набором характеристик. Яскравість сприймання в міських жителів приглушена побутом і відірваністю від природи, місто сприяє 
втраті індивідуальності. В одному з ліричних відступів Дара Корній так тлумачить сірий колір: «Змімали червоний, зелений та синій - зродилося сіре марево. Так, лише сіре, бо чорне - ие лишень відсутність потоку світла...» [Корній 2010:14]. У міфопоетиці «Гонихмарника» ключовий зелений колір (як символ буяння природного життя) стає ситуативним антонімом сірого. У «Злі» ж через акцентованість межі реальності і сну важливий для героїні-максималістки сірий колір відсунутий на другий план (4\%).

Найважливіше в сірому в контексті фентезійної логіки посередництво «між світлом і темрявою» [Браэм 2009:126]; поєднуючи ці протилежності, він символізує, зокрема, виснаженість і втому, самотність (до слова, втіленням посередництва між світами дійсності і сну у «Злі» й «Мантрі-омані» $є$ чорний кіт героїнь). Помітна частка в обговорюваних творах кольороназв сірого може бути аргументом i для підтвердження тенденції «згладжування» в сучасному фентезі конфлікту добра і зла, для чого тут висувається третя сторона. Так, специфіка модельованого Дарою Корній світу полягає, зокрема, в своєрідності морально-етичних акцентів при «нівелюванні» бінарності «добро - зло»; ново звучить тут думка про взаємозумовлене співіснування світла і темряви.

Практично невід'ємно пов'язаний зі сферою непізнанного, магічного, дивовижного, який традиційно символізує прагнення до свободи й водночас - ілюзорність, срібний колір у романах письменниць отримує середні статистичні показники присутності: максимальний вияв його в текстах «Гонихмарника» (7,3\% уживань кольороназв) $\mathrm{i}$ «Бурецвіта» (4,22\%). Так, у творі Дари Корній цей колір атрибутивний до опису магічної сили Гонихмарника [Корній 2010:64], а в «Бурецвіті» поєднується з золотим і відносно органічний у характеристиці квітки папороті.

Обсяг і роль червоного кольору в книгах помітно применшені щодо очікуваного - відповідно 7,3 \%, 9,6 \% і 4,9\% від уживань кольороназв у 
текстовій тканині «Гонихмарника», «Бурецвіта» і «Мантри-омани», - що пов’язано, в першу чергу, з актуалізованою в письменниць символізацією цим кольором не пристрасті, кохання, але спектру негативних переживань: небезпеки, сорому, заборони, попередження, агресії, страху. Так, у «Гонихмарнику» червоний викликає асоціації з неминучістю майбутнього нещастя (Аліна бачить уві сні червоний напис на дверях «Жереб кинуто» [Корній 2010:252]), позначений семами «лють», «страх», «тривога» й асоціативно пов'язаний із силами зла («страшні, червоні, люті очі» каміння [Корній 2010:311], падіння чорного сонця «в пащуеку червоної гори» [Корній 2010:310] і под.). У тексті М. Ряполової червоний також асоціюється, швидше, з негативними емоціями персонажів, зокрема, вказує на заборону, сором [Ряполова 2010:24]. Тільки у «Злі» показник червоного сягає 26,2 \% власне «завдяки» супроводженню відповідними лексемами описів інтимних переживань героїні.

Класичне символічне поле, але послаблена присутність у досліджуваних романах кольоративів на позначення жовтого (від 1 \% у тексті «Гонихмарника» до 7,7 \% - у «Бурецвіті»), рожевого (від 3,1\% у творі Дари Корній до 4,9\% - у тексті В. Гранецької). Не випадковий, очевидно, в корпусі «жіночої» прози різко зменшений відсоток червоного і жовтого - кольорів чоловічого начала [див.: Браэм 2009:153].

Фактор кольору в аналізованих романах Л. Баграт, Дари Корній, М. Ряполової й В. Гранецької, як бачимо, вельми важливий; по суті, колір тут бере участь у формуванні міфопоетики (до слова, героїня «Гонихмарника» - художник, а «Бурецвіта» - флорист), не тільки підкреслюючи, скажімо, характер персонажів та їх психологічний стан. Переконані, що вивчення закономірностей колористики ширшого кола української «жіночої» прози, а також включення результатів цього студіювання до компаративістичних досліджень прози XXI ст. сприятиме глибшому розумінню психології творчості сучасної національної 
письменниці і загалом процесів міжкультурної взаємодії українського митця і світової літератури.

\section{БІБЛІОГРАФІЯ}

Баграт 2002 - Баграт Л. Зло / Л. Баграт. - Львів : Кальварія, 2002. 288 c.

Браэм 2009 - Браэм Г. Психология цвета / Гаральд Браэм ; пер. с нем. М. В. Крапивкиной. - М. : АСТ : Астрель, 2009. - 158, [2] с.

Гранецька 2011 - Гранецька В. Мантра-омана : роман / Вікторія Гранецька. - Харків : Книжковий клуб «Клуб Сімейного Дозвілля», 2011. $240 \mathrm{c}$.

Гурдуз 2015 - Гурдуз А. І. Логіка кольору в романах Дари Корній «Гонихмарник» і М. Ряполової «Бурецвіт» / А. І. Гурдуз, В.В.Кедик // Науковий вісник : зб. наук. пр. / Миколаїв. нац. ун-т ім. В. О. Сухомлинського. Сер. : Філологічні науки (літературознавство). Миколаїв, 2015. - Вип. 1 (15).

Гурдуз 2014 - Гурдуз А. I. Комбінаторна міфопоетика роману Вікторії Гранецької «Мантра-омана» / А. I. Гурдуз // Studia methodologica.Тернопіль : РВВ ТНПУ ім. В. Гнатюка, 2014. - Вип. 38. - С. 138-144.

Гурдуз 2014 Міфопоетика - Гурдуз А. I. Міфопоетика «жіночого» містичного любовного роману першого десятиліття XXI ст. в Україні / А. Гурдуз // Науковий вісник : зб. наук. пр. / Миколаїв. держ. ун-т ім. В.О. Сухомлинського. Сер. : Філологічні науки. - Миколаїв, 2014. Вип. 4.13 (104). - С. 61-68.

Гурдуз 2012 - Гурдуз А. Роман Дари Корній «Гонихмарник»: місце в мистецькому контексті з погляду традиції й новаторства / А. Гурдуз // Українознавчий альманах. - .; Мелітополь. - 2012. - Вип. 9. C. 229-235.

Корній 2010 - Корній Д. Гонихмарник / Дара Корній ; передм. Люко Дашвар. - Харків : Книжковий клуб «Клуб сімейного дозвілля», 2010. $336 \mathrm{c}$.

Ряполова 2010 - Ряполова М. Бурецвіт [Електронний ресурс] / М. Ряполова. - Режим доступу : http://fb2.booksgid.com/content/96/marya- 
ryapolova-burecvt/1-40.html. 